\title{
Assessment of Yatta Canal Water Quality for Irrigation, Machakos County, Kenya
}

Manohar S*, Mang'oka JM, Ndunda E and Gathuru G

Department of Environmental Sciences, Kenyatta University, Nairobi, Kenya

\begin{abstract}
Water is one of the most important global requirements for every activity in life but if it is polluted/contaminated, then it creates direct problems of alkalinity/salinity/toxicity through irrigation to agricultural farms and affects on the quality and nutritional value of cultivated crops. Water quality of Yatta Canal was studied from January to December, 2015 within Machakos County of Kenya. Twenty sampling stations were selected at an interval of $1 \mathrm{~km}$ along this canal and water samples were collected once in a month during the wet and dry seasons to monitor its suitability for irrigation. Annual average values of temperature, $\mathrm{pH}$, total dissolved solids, turbidity, dissolved oxygen, and electrical conductivity show significant $(\mathrm{P}<0.05)$ seasonal variation. Annual average chemical concentrations of the water during wet and dry seasons are; Nitrates $13.1 \pm 0.47 \mathrm{mg} / \mathrm{l}$ vs $4.8 \pm 0.13 \mathrm{mg} / \mathrm{l}$; Phosphates $0.02 \pm 0.001 \mathrm{mg} / \mathrm{l} \mathrm{vs} 0.02 \pm 0.001 \mathrm{mg} / \mathrm{l}$; Potassium $3.8 \pm 0.098 \mathrm{mg} / \mathrm{l}$ vs $2.8 \pm 0.031 \mathrm{mg} / \mathrm{l}$; Sulphates $10.7 \pm 0.31 \mathrm{mg} / \mathrm{l}$ vs $7.2 \pm 0.25 \mathrm{mg} / \mathrm{l}$; Bicarbonates $46.9 \pm 1.20$ $\mathrm{mg} / \mathrm{l}$ vs $79.9 \pm 2.06 \mathrm{mg} / \mathrm{l} ;$ Chlorides $14.3 \pm 0.59 \mathrm{mg} / \mathrm{l}$ vs $2.0 \pm 0.10 \mathrm{mg} / \mathrm{l} ;$ Sodium $14.7 \pm 0.436 \mathrm{mg} / \mathrm{l}$ vs $17.7 \pm 0.200 \mathrm{mg} / \mathrm{l}$; Calcium $5.9 \pm 0.124 \mathrm{mg} / \mathrm{l}$ vs $8.1 \pm 0.058 \mathrm{mg} / \mathrm{l}$; Magnesium $2.2 \pm 0.020 \mathrm{mg} / \mathrm{l}$ vs $2.9 \pm 0.029 \mathrm{mg} / \mathrm{l}$, Sodium Adsorption Ratio $1.30 \pm 0.030 \mathrm{me} / \mathrm{l}$ vs $1.35 \pm 0.020 \mathrm{me} / \mathrm{l}$ and Iron $0.49 \pm 0.007 \mathrm{mg} / \mathrm{l}$ vs $0.64 \pm 0.041 \mathrm{mg} / \mathrm{l}$ respectively. These chemical parameters also show significant $(\mathrm{P}<0.05)$ seasonal variation. Most of the physical and chemical levels are within the permissible limits as recommended by FAO and also by Kenya's National Environment Management Authority with the exception of turbidity (100.2 NTU) and nitrate concentration (13.1 mg/l) only during the wet season. Based on the results, the canal water is safe for irrigation during dry season.
\end{abstract}

Keywords: Irrigation; Water quality; Yatta canal; Kenya

\section{Introduction}

In Kenya, rainfed agriculture is one of the main economic activities for the production of crops. Due to erratic rainfall in most of the arid and semi arid areas, the risk of crop failure is common within small scale farmers who suffer due to lack of water for irrigation. Wherever irrigation is possible, it is necessary to monitor the water quality in order to ensure sustainable crop yields. In dry season, high nutrient enrichment causes eutrophication which is the indication of toxicity in water bodies especially in small dams, canals or slow flowing shallow rivers due to seasonal water level fluctuations and high rate of evaporation in arid and semi-arid areas. Water quality shows current status about the concentration of various solutes at a given place and time [1]. The water quality parameters provide a basis for judging the suitability of water for its designated uses and to improve existing conditions [2].

Irrigation water quality is a key environmental issue faced by the agricultural sector [3]. Agricultural practices with agrochemicals result to chemical pollution of water bodies and over time cumulative effects lead to the depletion of water quality [4]. Sources of water pollution associated with agricultural systems include pesticides, insecticides, herbicides, animal dung/ manure, nitrates, phosphates and other chemical fertilizers, heavy metals, pathogens and sediment load. These pollutants cause potential ecological imbalances and direct health hazards to local people who depend on the water and products from agriculture $[5,6]$.

This canal is a main water resource and the only single water supply for irrigation and domestic uses within the arid and semi-arid area of Yatta Constituency in Machakos County, Kenya [7]. During the pre-colonial era in December 1953, excavation of the canal from the proposed intake along Thika River began using Mau Mau detainees in order to supply water for domestic, irrigation and livestock use $[8,9]$. African Land Development Board (ALDEV) financed the construction and completed this canal for operation on $18^{\text {th }}$ September 1959 [8].
Increasing demand for water due to population growth and agricultural activities has led to massive siltation in the canal over the years. This has subsequently reduced the flow rate especially during dry season [10]. Increased use and infiltration of agrochemicals, poor farming, and irrigation practices as well as rainfall variability has led to contamination of the canal water. Therefore, the study was conducted to analyze the levels of physico-chemical parameters to monitor the irrigation water quality of canal during wet and dry seasons.

\section{Materials and Methods}

\section{Study area}

Yatta Canal is $60 \mathrm{~km}$ long located between longitudes $(0.80 \mathrm{~W}$, $1.270 \mathrm{E})$ and latitudes $(36.660 \mathrm{~N}, 37.100 \mathrm{~S})$ at an altitude of about 1525 $\mathrm{m}$ above sea level in Yatta Constituency of Machakos County, Kenya (Figure 1). Main soil types are Acrisols, Luvisols, Ferralsols, Alfisols, Ultisols, Oxisols and Lithisols [11-13] of low fertility and many are highly erodible. Yatta Constituency covers land area of $1,057 \mathrm{Km}^{2}$ with 147,579 people $[14,15]$ and experience arid climates due to erratic precipitation and has low agricultural potential due to frequent droughts.

About $70 \%$ population in Yatta depends on agriculture for their livelihoods and poverty level is $67.5 \%$ [14]. Most of the farmers practice

*Corresponding author: Manohar S, Department of Environmental Sciences, Kenyatta University, PO Box 43844-00100 Nairobi, Kenya, Tel: +254738974888; E-mail: prof.dr.smanohar@gmail.com (or) jmangoka@gmail.com

Received December 04, 2016; Accepted December 13, 2016; Published January 03, 2017

Citation: Manohar S, Mang'oka JM, Ndunda E, Gathuru G (2017) Assessment of Yatta Canal Water Quality for Irrigation, Machakos County, Kenya. J Environ Anal Toxicol 7: 423. doi: 10.4172/2161-0525.1000423

Copyright: () 2017 Manohar S, et al. This is an open-access article distributed under the terms of the Creative Commons Attribution License, which permits unrestricted use, distribution, and reproduction in any medium, provided the original author and source are credited. 
Citation: Manohar S, Mang'oka JM, Ndunda E, Gathuru G (2017) Assessment of Yatta Canal Water Quality for Irrigation, Machakos County, Kenya. J Environ Anal Toxicol 7: 423. doi: 10.4172/2161-0525.1000423

Page 2 of 6

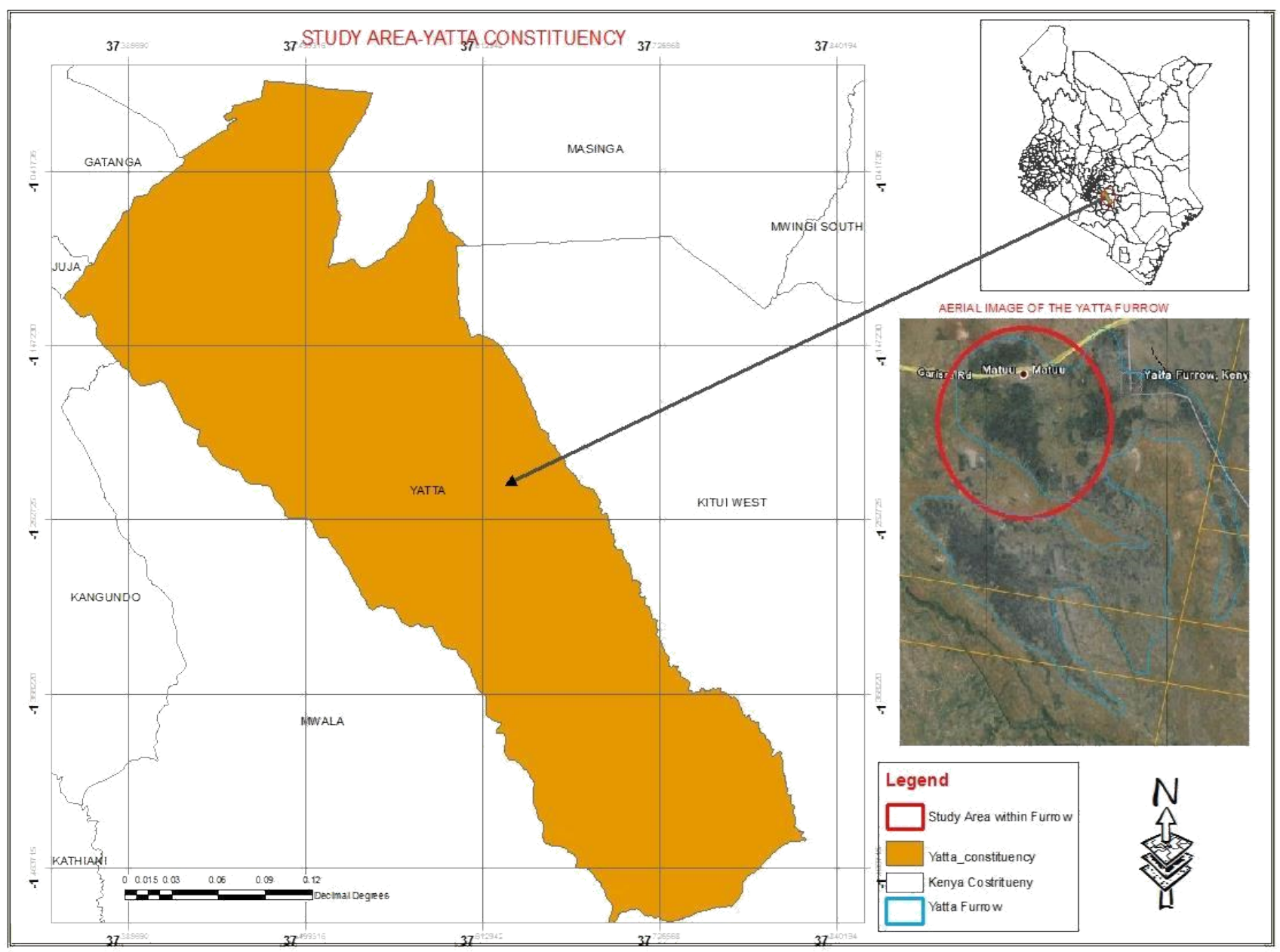

Figure 1: Map of Kenya shows Yatta Constituency in Machakos County, Kenya (Source: Machakos County Integrated Development Plan [15]).

small scale agriculture and cultivate during the short rains but use canal water for irrigation depending on the need. Main cultivated crops in this area are; Zea mays (maize), Phaseolus vulgaris (beans), Pennisetum glaucum (millet), Sorghum vulgare (sorghum), Manihot esculenta (cassava), Mangifera indica (mango), Citrullus lanatus (water melon), Phaseolus vulgaris L. (French bean), Musa acuminata (banana) and Lycopersicon esculentum L. (tomato). To supplement household incomes, people also practice cattle herding, poultry and bee keeping (Figure 1).

\section{Data collection and analysis}

Water samples were collected once in a month from twenty sampling stations along the canal at intervals of $1 \mathrm{~km}$ from the main intake (Figure 2) to analyze physical and chemical characteristics during wet and dry seasons of the year 2015. Systematic grid sampling method was used to identify the water sample collection points within mid depth of the canal. Prior to water sampling, the bottles were cleaned with $10 \%$ nitric acid and rinsed with distilled water. They were then rinsed three times with the canal water at the time of sampling. Water samples were collected midstream at the depth of $20 \mathrm{~cm}$ using a longhandled water scooper and filled in the $500 \mathrm{ml}$ plastic bottles with screw caps. Samples for the analysis of metals were immediately acidified to $\mathrm{pH}$ value of 2.0 using reagent grade nitric acid to reduce adsorption of metals onto the walls of the plastic bottles [16]. The sample bottles were labelled, kept in an icebox, and transported for laboratory analysis within 24 hours of collection.

Water temperature and electrical conductivity were measured using a portable multi electrode water testing kit (Portable OakTon 510 series) equilibrated to $25^{\circ} \mathrm{C}$ while $\mathrm{pH}$ was measured using a calibrated $\mathrm{pH}$ meter. Dissolved oxygen was measured using an Oxygen meter while turbidity and total dissolved solids were determined using Turbidity and Digital TDS meters respectively. Major cations $\left(\mathrm{Na}^{+}, \mathrm{Ca}^{2+}, \mathrm{Mg}^{2+}\right.$, $\mathrm{Fe}^{2+}$ and $\mathrm{K}^{+}$) were determined using Flame Photometer Model 410. Sulphates, nitrates and phosphates were measured using UV Visible spectrophotometer. Chlorides were determined by titration against $\mathrm{AgNO}_{3}$ solution to pinkish yellow end point using $\mathrm{K}_{2} \mathrm{CrO}_{4}$ as indicator solution while $\mathrm{HCO}_{3}^{-}$were determined by titrating water samples against $\mathrm{H}_{2} \mathrm{SO}_{4}$ to phenolphthalein and methyl orange indicator end points [17]. Paired t-test was done to compare variations in the average annual values of the physical and chemical characteristics of canal water during wet and dry seasons to note the significant differences at $\mathrm{p} \leq 0.05$ level [18].

\section{Results and Discussion}

\section{Physical parameters}

The annual average values of physical characteristics of the canal water are mentioned (Table 1). Water temperature is between $21^{\circ} \mathrm{C}$ 
Citation: Manohar S, Mang'oka JM, Ndunda E, Gathuru G (2017) Assessment of Yatta Canal Water Quality for Irrigation, Machakos County, Kenya. J Environ Anal Toxicol 7: 423. doi: 10.4172/2161-0525.1000423

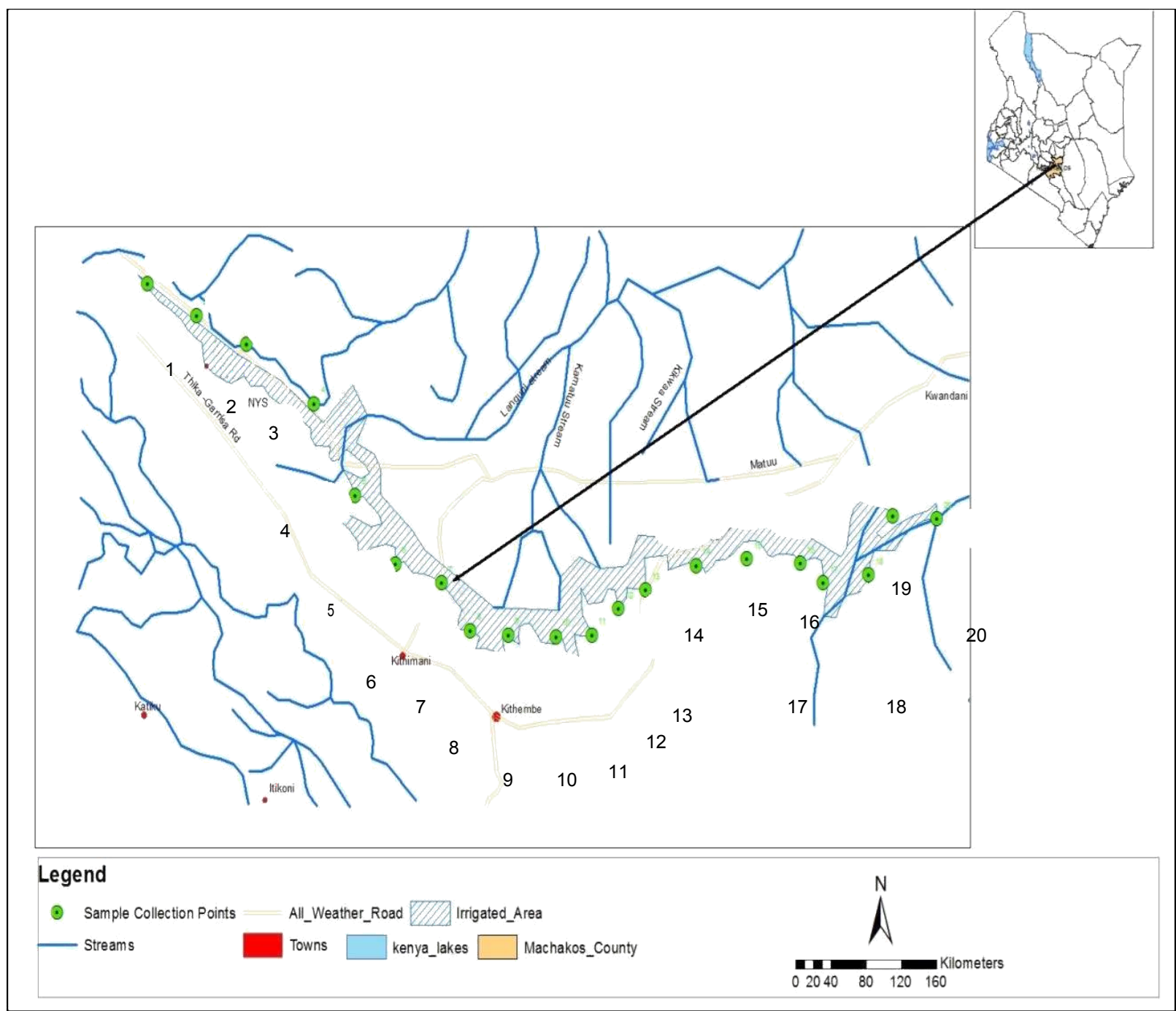

Figure 2: Map of study area shows sampling stations (1-20) selected along Yatta Canal flowing in Yatta Constituency of Machakos County, Kenya (January-December 2015).

to $24.5^{\circ} \mathrm{C}$ (mean value of $22.6 \pm 0.19^{\circ} \mathrm{C}$ ) during the wet and $24.8^{\circ} \mathrm{C}$ to $26.1^{\circ} \mathrm{C}$ (mean value of $25.4 \pm 0.08^{\circ} \mathrm{C}$ ) in dry seasons respectively. Using paired t-test, mean temperature values show significant seasonal variation $(\mathrm{P}=0.001, \mathrm{~T}=15.304)$. The canal water temperature is higher during dry than wet season due to slow water flow and increased solar radiation. Variations in water temperatures are influenced by land use changes, slow flow rate, intensity and duration of solar radiation and fluctuations in precipitation [19-21].

The $\mathrm{pH}$ values vary from 6.85 to 7.54 (mean value of $7.2 \pm 0.04$ ) during wet and 6.73 to 8.01 (mean value of $7.4 \pm 0.08$ ) in dry seasons. These levels however show significant $(\mathrm{P}=0.003, \mathrm{~T}=3.416)$ seasonal variation. The slight difference in mean $\mathrm{pH}$ value is due to dilution from rain water and the stirring effect of incoming surface runoff from streams and agricultural farms resulting in mixing of water in canal. High temperatures and decomposition of organic matter during dry season decrease the amount of dissolved oxygen but increase the amount of carbon dioxide which reflects on high levels of carbonates and bicarbonates to show high $\mathrm{pH}$ levels. Similar observation was reported in Jebba lake Nigeria [22].
During the study period, total dissolved solids exhibit wide variation between wet and dry seasons. Mean TDS values are $439.4 \pm$ $8.41 \mathrm{mg} / \mathrm{l}$ during wet and $319.3 \pm 8.10 \mathrm{mg} / \mathrm{l}$ in dry season. These values differ significantly $(\mathrm{P}=0.001, \mathrm{~T}=-30.452)$ across the sampling seasons. The concentrations are significantly high during wet season due to erosion of particulate matter and sediments from agricultural fields into the canal water. Similar results were also noticed due to surface runoff from agricultural farms along water sources [23,24].

Mean turbidity values of the canal water are $100 \pm 3.41 \mathrm{NTU}$ and $47.7 \pm 5.51 \mathrm{NTU}$ in wet and dry seasons respectively. Paired t-test shows significant $(\mathrm{P}=0.001, \mathrm{~T}=-7.60)$ seasonal variation during the study period. Low turbidity values during dry season are attributed to the slow flow rate which allows suspended particles and silt to settle. Poor cultivation practices, deforestation and soil erosion have also been identified as main factors that lead to increased turbidity and sediment loads in water sources [25].

Dissolved oxygen values are between $4.2 \mathrm{mg} / \mathrm{l}$ to $8.6 \mathrm{mg} / \mathrm{l}$ (average value of $6.6 \pm 0.33 \mathrm{mg} / \mathrm{l}$ ) during wet and $3.7 \mathrm{mg} / \mathrm{l}$ to $8.1 \mathrm{mg} / \mathrm{l}$ (average value of $6.0 \pm 0.38 \mathrm{mg} / \mathrm{l}$ ) in dry seasons. Paired t-test results show a 
Citation: Manohar S, Mang'oka JM, Ndunda E, Gathuru G (2017) Assessment of Yatta Canal Water Quality for Irrigation, Machakos County, Kenya. J Environ Anal Toxicol 7: 423. doi: 10.4172/2161-0525.1000423

Page 4 of 6

\begin{tabular}{|c|c|c|c|c|c|c|c|c|c|c|c|c|}
\hline \multirow{2}{*}{$\begin{array}{l}\text { Sampling } \\
\text { stations }\end{array}$} & \multicolumn{2}{|c|}{ Temp $\left({ }^{\circ} \mathrm{C}\right)$} & \multicolumn{2}{|c|}{$\mathrm{pH}$} & \multicolumn{2}{|c|}{$\begin{array}{c}\text { Total dissolved solids } \\
(\mathrm{mg} / \mathrm{l})\end{array}$} & \multicolumn{2}{|c|}{ Turbidity (NTU) } & \multicolumn{2}{|c|}{$\begin{array}{c}\text { Dissolved oxygen } \\
(\mathrm{mg} / \mathrm{l})\end{array}$} & \multicolumn{2}{|c|}{$\begin{array}{l}\text { Electrical conductivity } \\
(\mathrm{dS} / \mathrm{m})\end{array}$} \\
\hline & Wet & Dry & Wet & Dry & Wet & Dry & Wet & Dry & Wet & Dry & Wet & Dry \\
\hline 1 & 22.4 & 26 & 7.36 & 7.37 & 435.7 & 300.0 & 105.2 & 45.7 & 8.0 & 8.1 & 0.16 & 0.17 \\
\hline 2 & 22.1 & 25 & 6.97 & 7.18 & 416.3 & 279.3 & 108.1 & 30.5 & 7.5 & 8 & 0.18 & 0.16 \\
\hline 3 & 21 & 25.2 & 6.85 & 6.95 & 402.0 & 277.7 & 86.1 & 25.9 & 8.2 & 8 & 0.17 & 0.12 \\
\hline 4 & 21.7 & 25.2 & 7.0 & 6.73 & 390.0 & 272.3 & 71.5 & 24.4 & 8.5 & 8.2 & 0.16 & 0.12 \\
\hline 5 & 21.9 & 24.8 & 6.94 & 7.02 & 388.1 & 290.4 & 103.2 & 26 & 8.6 & 7.8 & 0.16 & 0.13 \\
\hline 6 & 21.4 & 25.2 & 7.17 & 7.3 & 391.0 & 303.0 & 123.7 & 23.7 & 8.6 & 8 & 0.16 & 0.16 \\
\hline 7 & 22.3 & 25.4 & 7.23 & 7.22 & 406.3 & 284.0 & 122 & 25.5 & 8.0 & 7.2 & 0.16 & 0.14 \\
\hline 8 & 22.5 & 25.9 & 7.18 & 7.26 & 413.3 & 335.3 & 114.4 & 63.6 & 6.9 & 4.2 & 0.16 & 0.12 \\
\hline 9 & 22.5 & 26.1 & 7.16 & 7.43 & 428.0 & 318.0 & 84.7 & 41.3 & 6.6 & 7.3 & 0.16 & 0.12 \\
\hline 10 & 22.3 & 25.5 & 7.28 & 7.45 & 434.3 & 304.7 & 108.7 & 41 & 6.2 & 6.7 & 0.16 & 0.12 \\
\hline 11 & 22.4 & 25.1 & 7.41 & 7.43 & 432.7 & 312.0 & 119.6 & 46.7 & 7.2 & 6.4 & 0.16 & 0.12 \\
\hline 12 & 22.3 & 25.2 & 7.47 & 7.4 & 434.3 & 303.0 & 92.9 & 31.2 & 6.4 & 5.7 & 0.16 & 0.13 \\
\hline 13 & 22.6 & 25.1 & 7.28 & 7.24 & 462.3 & 304.0 & 103.4 & 30 & 5.8 & 5.5 & 0.16 & 0.13 \\
\hline 14 & 22.8 & 25.1 & 7.16 & 7.46 & 457.3 & 316.3 & 98.4 & 28.3 & 5.7 & 4.7 & 0.16 & 0.12 \\
\hline 15 & 22.8 & 25.1 & 7.14 & 7.57 & 460.7 & 336.3 & 101.7 & 42 & 5.3 & 4.4 & 0.16 & 0.12 \\
\hline 16 & 22.8 & 25.3 & 7.07 & 7.87 & 470.7 & 354.7 & 80.1 & 73.4 & 5.4 & 3.7 & 0.16 & 0.12 \\
\hline 17 & 22.9 & 25.3 & 7.15 & 8.01 & 475.7 & 359.7 & 76.9 & 83.2 & 4.8 & 4.5 & 0.16 & 0.13 \\
\hline 18 & 23.6 & 25.5 & 7.33 & 7.99 & 473.7 & 363.3 & 86.2 & 88.4 & 5.0 & 4.1 & 0.17 & 0.13 \\
\hline 19 & 24.5 & 25.3 & 7.54 & 7.97 & 502.0 & 383.3 & 106.0 & 91 & 4.4 & 4.4 & 0.17 & 0.16 \\
\hline 20 & 24.5 & 26 & 7.45 & 7.78 & 512.7 & 388.7 & 111.6 & 91.3 & 4.2 & 3.7 & 0.18 & 0.14 \\
\hline Mean \pm SE & $22.6 \pm 0.19$ & $25.4 \pm 0.08$ & $7.2 \pm 0.04$ & $7.4 \pm 0.08$ & $\begin{array}{c}439.4 \pm \\
8.41\end{array}$ & $\begin{array}{c}319.3 \pm \\
8.10\end{array}$ & $\begin{array}{c}100.2 \pm \\
3.41\end{array}$ & $47.7 \pm 5.51$ & $6.6 \pm 0.33$ & $6.0 \pm 0.38$ & $\begin{array}{l}0.16 \pm \\
0.002\end{array}$ & $\begin{array}{l}0.13 \pm \\
0.003\end{array}$ \\
\hline
\end{tabular}

Table 1: Mean annual Physical parameters of water collected during wet and dry seasons from twenty sampling stations along Yatta Canal (Jan-Dec 2015) in Machakos County, Kenya.

significant $(\mathrm{P}=0.006, \mathrm{~T}=-3.088)$ seasonal variation. Low levels of dissolved oxygen in the canal water are due to slow flow rate, low turbulence, low aeration, and longer exposure to solar radiation.

Electrical conductivity is between $0.16 \pm 0.002 \mathrm{dSm}^{-1}$ and $0.13 \pm 0.003$ $\mathrm{dSm}^{-1}$ in wet and dry seasons respectively and has significant $(\mathrm{P}=0.001$, $\mathrm{T}=8.868$ ) seasonal variation. The $\mathrm{EC}$ values depend on the amount of dissolved materials in water [26]. Higher electrical conductivity is noted in wet season than in dry due to leaching/infiltration of salts and nutrients. High chloride, phosphate and nitrate contents associated with agriculture increase electrical conductivity $[27,28]$. Variations in conductivity are due to slow flow rate, dissolved solids from agricultural farms, dilution by rainfall, ion exchange between sediments, water and submerged organic matter (Table 1) [29].

\section{Chemical parameters}

Annual average values of $\mathrm{Ca}^{2+}, \mathrm{Mg}^{2+}, \mathrm{Na}^{+}, \mathrm{K}^{+}, \mathrm{Fe}^{2+}, \mathrm{HCO}_{3}^{-}, \mathrm{NO}_{3}$ , $\mathrm{SO}_{4}^{2-}, \mathrm{PO}_{4}^{3-}$ and $\mathrm{Cl}^{-}$ions are presented in Table 2. Mean calcium value is $5.9 \pm 0.124 \mathrm{mg} / \mathrm{l}$ during wet and $8.1 \pm 0.058 \mathrm{mg} / \mathrm{l}$ in dry season. Using paired t-test, mean calcium values show significant $(\mathrm{P}=0.001, \mathrm{~T}=15.438)$ seasonal variation. Low levels of calcium are due to dilution during rainy season. Calcium levels in surface water are also influenced by the carbonate balance [30] and organic compounds contaminated with waste water [31] which enter water sources through mineral leaching.

Magnesium concentrations are $2.23 \pm 0.02 \mathrm{mg} / \mathrm{l}$ and $2.88 \pm$ $0.029 \mathrm{mg} / \mathrm{l}$ during wet and dry seasons respectively. The results show significant variation $(\mathrm{P}=0.001, \mathrm{~T}=30.301)$ across the sampling seasons. Magnesium is an essential micronutrient for chlorophyll and acts as a limiting factor for the growth of phytoplankton. Depletion of magnesium reduces phytoplankton population in aquatic ecosystems [32].

Sodium values are $14.7 \pm 0.436 \mathrm{mg} / \mathrm{l}$ and $17.7 \pm 0.2 \mathrm{mg} / \mathrm{l}$ during wet and dry seasons respectively. Water quality for irrigation is also determined by the absolute and relative concentration of cations. The proportion of sodium $\left(\mathrm{Na}^{+}\right)$to calcium $\left(\mathrm{Ca}^{2+}\right)$ and magnesium $\left(\mathrm{Mg}^{2+}\right)$ ions in a water sample is expressed as SAR which is an important parameter to determine the water quality and responsible for the sodium hazard in irrigation water [33]. SAR values are $1.3 \pm 0.030 \mathrm{me} / \mathrm{l}$ during wet and $1.35 \pm 0.020 \mathrm{me} / \mathrm{l}$ in dry seasons. Sodium concentration increases in dry season and decreases in the rainy season due to dilution $[34,35]$.

Potassium levels are $3.8 \pm 0.098 \mathrm{mg} / \mathrm{l}$ and $2.8 \pm 0.031 \mathrm{mg} / \mathrm{l}$ during wet and dry seasons respectively. Potassium levels are higher in canal water within wet season due to surface runoff and leaching from agricultural farms to the canal. Using paired $\mathrm{t}$-test, the results show significant seasonal variation $(\mathrm{P}=0.001, \mathrm{~T}=-9.506)$. Potassium concentrations increase in water bodies due to salts and nutrients leached to the water table during rainy season [36].

Nitrate levels are between $3.5 \mathrm{mg} / \mathrm{l}$ to $5.8 \mathrm{mg} / \mathrm{l}$ during dry and 10.8 $\mathrm{mg} / \mathrm{l}$ to $18.8 \mathrm{mg} / \mathrm{l}$ in wet season with average values of $4.8 \pm 0.13 \mathrm{mg} / \mathrm{l}$ and $13.1 \pm 0.47 \mathrm{mg} / \mathrm{l}$ respectively. Mean nitrate concentration shows significant $(\mathrm{P}=0.001, \mathrm{~T}=-20.723)$ variation across the seasons. High nitrate levels in the canal water are due to surface runoff and nutrient leaching from agricultural farms. The use of animal manure and nitrogen fertilizers result in considerable enrichment of surface soils and subsequent runoff contains relatively high levels of nutrients, organic matter and suspended particles during or after rains [37,38]. Nutrients get eroded into surface waters and elevate nitrate concentrations.

Phosphate levels in canal water are $0.02 \pm 0.001 \mathrm{mg} / \mathrm{l}$ during both the dry and wet seasons and there's no significant seasonal variation. Phosphates in surface water arise from natural decomposition of rocks and minerals, weathering of soluble inorganic materials, decaying biomass, runoff, sedimentation, anthropogenic activities mainly fertilizers, waste water and septic system effluent, animal wastes, detergents, industrial discharge and surface construction $[39,40]$ (Table 2). 
Citation: Manohar S, Mang'oka JM, Ndunda E, Gathuru G (2017) Assessment of Yatta Canal Water Quality for Irrigation, Machakos County, Kenya. J Environ Anal Toxicol 7: 423. doi: 10.4172/2161-0525.1000423

Page 5 of 6

\begin{tabular}{|c|c|c|c|c|c|c|c|c|c|c|c|c|c|c|c|c|c|c|c|c|}
\hline \multirow{2}{*}{$\begin{array}{l}\text { Sampling } \\
\text { stations }\end{array}$} & \multicolumn{2}{|c|}{$\mathrm{Ca}^{2+}(\mathrm{mg} / \mathrm{l})$} & \multicolumn{2}{|c|}{$\mathrm{Mg}^{2+}(\mathrm{mg} / \mathrm{l})$} & \multicolumn{2}{|c|}{$\mathrm{Na}^{+}(\mathrm{mg} / \mathrm{l})$} & \multicolumn{2}{|c|}{$\mathrm{K}^{+}(\mathrm{mg} / \mathrm{l})$} & \multicolumn{2}{|c|}{$\mathrm{Fe}^{2+}(\mathrm{mg} / \mathrm{l})$} & \multicolumn{2}{|c|}{$\mathrm{HCO}_{3} \cdot(\mathrm{mg} / \mathrm{l})$} & \multicolumn{2}{|c|}{$\mathrm{NO}_{3}^{-}(\mathrm{mg} / \mathrm{l})$} & \multicolumn{2}{|c|}{$\mathrm{SO}_{4}^{2-}(\mathrm{mg} / \mathrm{l})$} & \multicolumn{2}{|c|}{$\mathrm{PO}_{4}^{3-}(\mathrm{mg} / \mathrm{l})$} & \multicolumn{2}{|c|}{$\mathrm{Cl}^{-}(\mathrm{mg} / \mathrm{l})$} \\
\hline & Wet & Dry & Wet & Dry & Wet & Dry & Wet & Dry & Wet & Dry & Wet & Dry & Wet & Dry & Wet & Dry & Wet & Dry & Wet & Dry \\
\hline 1 & 6.61 & 8.12 & 2.32 & 3.03 & 18.1 & 17.2 & 3.80 & 3.09 & 0.52 & 0.45 & 3.3 & 81.4 & 14.2 & 5.33 & 10.5 & 6.25 & 0.020 & 0.018 & 18.5 & 2.60 \\
\hline 2 & 6.42 & 8.16 & 2.35 & 3.08 & 17.7 & 16.9 & 3.74 & 3.08 & 0.51 & 0.40 & 48.3 & 76.7 & 14.6 & 5.37 & 9.97 & 6.15 & 0.019 & 0.017 & 17.7 & 2.48 \\
\hline 3 & 6.71 & 8.15 & 2.23 & 2.90 & 17.4 & 16.1 & 3.57 & 2.95 & 0.48 & 0.37 & 40.8 & 73.7 & 10.9 & 5.17 & 11.0 & 6.02 & 0.019 & .022 & 17.5 & 2.38 \\
\hline 4 & 6.71 & 8.18 & 2.22 & 2.79 & 17.0 & 16.1 & 3.76 & 2.83 & 0.48 & 0.45 & 44.7 & 62.5 & 12.1 & 4.99 & 12.1 & 5.90 & 0.019 & .019 & 15.4 & 2.32 \\
\hline 5 & 58 & 8.10 & 2.17 & 2.71 & 16.6 & 16.3 & 3.80 & 2.82 & 0.50 & 0.47 & 48.6 & 59.2 & 12.4 & 5.13 & 11.8 & 5.84 & 018 & .021 & 15.0 & 2.19 \\
\hline 6 & 6.67 & 8.08 & 2.18 & 2.63 & 17.0 & 17.1 & 2.85 & 2.87 & 0.50 & 0.53 & 51.4 & 67.6 & 14.5 & 5.13 & 11.1 & 6.0 & .018 & 0.021 & 12.3 & 2.23 \\
\hline 7 & 6.09 & 7.97 & 2.25 & 2.68 & 15.8 & 17.2 & 2.86 & 2.81 & 0.51 & 0.60 & 48.5 & 71.5 & 12.2 & 4.92 & 10.7 & 6.45 & 0.021 & 0.02 & 11.2 & 2.20 \\
\hline 8 & 5.40 & 8.19 & 2.13 & 2.89 & 14.2 & 17.3 & 3.47 & 2.84 & 0.49 & 0.57 & 42.9 & 76.0 & 11.2 & 4.55 & 9.35 & 6.66 & 0.021 & 0.018 & 11.3 & 2.18 \\
\hline 9 & 5.49 & 8.28 & 2.26 & 2.91 & 14.1 & 17.6 & 3.68 & 2.75 & 0.50 & 0.60 & 44.4 & 79.5 & 11.0 & 4.23 & 8.8 & 6.80 & 0.020 & 0.018 & 11.2 & 1.88 \\
\hline 10 & 5.83 & 8.43 & 2.35 & 3.03 & 13.9 & 17.3 & 3.61 & 2.80 & 0.47 & 0.61 & 49.3 & 81.0 & 13.3 & 4.04 & 8.6 & 7.07 & 0.019 & 0.02 & 11.2 & 1.78 \\
\hline 11 & 5.67 & 8.38 & 2.34 & 3.06 & 14.1 & 17.8 & 3.49 & 2.75 & 0.48 & 0.61 & 46.9 & 83.6 & 12.6 & 3.83 & 9.3 & 7.14 & 0.018 & 0.019 & 10.7 & 1.84 \\
\hline 12 & 5.35 & 8.33 & 2.27 & 2.79 & 13.7 & 17.8 & 3.65 & 2.76 & 0.48 & 0.62 & 41.7 & 86.8 & 11.8 & 3.53 & 9.9 & 7.20 & 0.018 & 0.019 & 12.3 & 1.44 \\
\hline 13 & 5.21 & 8.35 & 2.10 & 2.80 & 13.1 & 18.0 & 3.72 & 2.74 & 0.47 & 0.62 & 36.7 & 83.3 & 11.3 & 4.07 & 10.4 & 7.29 & 0.019 & 0.023 & 13.0 & 1.41 \\
\hline 14 & 5.19 & 8.41 & 2.13 & 2.85 & 13.2 & 18.4 & 3.83 & 2.74 & 0.46 & 0.67 & 40.4 & 84.2 & 10.8 & 4.48 & 11.0 & 7.27 & 0.016 & .022 & 13.5 & 1.44 \\
\hline 15 & 5.34 & 7.86 & 2.13 & 2.82 & 12.9 & 18.5 & 4.13 & 2.72 & 0.46 & 0.75 & 44.5 & 83.7 & 11.4 & 4.83 & 10.5 & 7.40 & 0.012 & 0.024 & 14.5 & 1.48 \\
\hline 16 & 5.42 & 7.76 & 2.10 & 2.85 & 12.3 & 18.6 & 4.28 & 2.75 & 0.47 & 0.77 & 48.4 & 83.5 & 12.1 & 5.02 & 10.3 & 7.43 & 0.013 & 0.025 & 14.9 & 1.60 \\
\hline 17 & 5.70 & 7.66 & 2.15 & 2.82 & 12.4 & 18.8 & 4.02 & 2.73 & 0.47 & 0.80 & 46.6 & 88.0 & 14.6 & 5.10 & 12.0 & 8.44 & 0.014 & 0.026 & 15.1 & 1.47 \\
\hline 18 & 5.92 & 7.45 & 2.20 & 2.85 & 12.6 & 18.5 & 4.37 & 2.74 & 0.51 & 0.89 & 47.6 & 90.5 & 14.9 & 5.08 & 10.5 & 8.74 & 0.015 & 0.022 & 15.3 & 1.46 \\
\hline 19 & 6.12 & 8.07 & 2.31 & 2.97 & 13.2 & 18.7 & 4.41 & 3.09 & 0.58 & 1.02 & 53.2 & 91.2 & 16.3 & 5.52 & 12.3 & 9.35 & 0.018 & .024 & 16.4 & 2.35 \\
\hline 20 & 6.42 & 8.21 & 2.37 & 3.07 & 14.0 & 18.9 & 4.48 & 3.12 & 0.55 & 1.01 & 60.6 & 93.1 & 18.8 & 5.80 & 14.5 & 9.60 & 0.016 & 0.026 & 19.1 & 2.54 \\
\hline ean \pm SE & $\begin{array}{l}5.9 \pm \\
0.124\end{array}$ & $\begin{array}{l}8.1 \pm \\
0.058\end{array}$ & $\begin{array}{c}2.23 \pm \\
0.02\end{array}$ & $\begin{array}{l}2.88 \pm \\
0.029\end{array}$ & $\begin{array}{l}14.7 \pm \\
0.436\end{array}$ & $\begin{array}{c}17.7 \pm \\
0.2\end{array}$ & $\begin{array}{l}3.8 \pm \\
0.098\end{array}$ & $\begin{array}{l}2.8 \pm \\
0.031\end{array}$ & $\begin{array}{l}0.49 \pm \\
0.007\end{array}$ & $\begin{array}{c}0.64 \pm \\
0.04\end{array}$ & $\begin{array}{c}46.9 \pm \\
1.2\end{array}$ & $\begin{array}{c}79.9 \pm \\
2.06\end{array}$ & $\begin{array}{c}13.1 \pm \\
0.47\end{array}$ & $\begin{array}{l}4.8 \pm \\
0.13\end{array}$ & $\begin{array}{c}10.7 \pm \\
0.31\end{array}$ & $\begin{array}{l}7.2 \pm \\
0.25\end{array}$ & $\begin{array}{l}0.02 \pm \\
0.001\end{array}$ & $\begin{array}{l}0.02 \pm \\
0.001\end{array}$ & $\begin{array}{c}14.3 \pm \\
0.59\end{array}$ & $\begin{array}{c}2.0 \pm \\
0.1\end{array}$ \\
\hline
\end{tabular}

Table 2: Mean annual chemical characteristics of water collected during wet and dry seasons from twenty sampling stations (1-20) along Yatta Canal in Machakos County, Kenya (Jan-Dec 2015)

Sulphate levels are $10.7 \pm 0.31 \mathrm{mg} / \mathrm{l}$ during wet and $7.2 \pm 0.25$ $\mathrm{mg} / \mathrm{l}$ in dry seasons. Using paired t-test, mean values show significant $(\mathrm{P}<0.05)$ variation across the two seasons $(\mathrm{P}=0.001 ; \mathrm{T}=-11.89)$. Higher sulphate levels during rainy season are attributed to surface runoff containing organic fertilizers from agricultural activities along the canal. Discharge of industrial wastes, surface runoff and domestic sewage tend to increase sulphate concentration in surface water [41].

Chloride levels are $14.3 \pm 0.59 \mathrm{mg} / \mathrm{l}$ during wet and $2.0 \pm 0.10$ $\mathrm{mg} / \mathrm{l}$ in dry seasons. Results also show significant seasonal variation $(\mathrm{P}=0.001 ; \mathrm{T}=-22.458)$. High concentration of chlorides during rainy season is attributed to addition of organic wastes of animal origin through surface runoff and use of pesticides on horticultural crops. Sewage water and industrial effluents are rich in $\mathrm{Cl}^{-}$and discharge of these wastes result in high chloride levels in fresh water bodies/ wetlands [42].

Iron concentrations are $0.64 \pm 0.041 \mathrm{mg} / \mathrm{l}$ during dry and $0.49 \pm$ $0.007 \mathrm{mg} / \mathrm{l}$ in wet seasons and shows significant seasonal variation $(\mathrm{P}=0.001, \mathrm{~T}=3.72)$. Increased iron concentration in the canal water is attributed to organic matter addition and decomposition during the dry season.

Bicarbonate levels in the canal water range between $36.7 \mathrm{mg} / \mathrm{l}$ to $60.6 \mathrm{mg} / \mathrm{l}$ during wet and $59.2 \mathrm{mg} / \mathrm{l}$ to $93.1 \mathrm{mg} / \mathrm{l}$ in dry seasons with average values being $46.9 \pm 1.2 \mathrm{mg} / \mathrm{l}$ and $79.9 \pm 2.06 \mathrm{mg} / \mathrm{l}$ respectively. Mean values show significant seasonal variation $(\mathrm{P}=0.001 ; \mathrm{T}=14.857)$. Higher concentration of bicarbonate at $79.9 \mathrm{mg} / \mathrm{l}$ and $\mathrm{pH} 7.4$ during the dry season is attributed to decomposition of organic matter in the canal due to slow flow rate. Bicarbonate levels in water also depend on weathering process in catchments, rate of photosynthesis, respiration and organic decomposition in water [43].

During the study period, it was noticed that in wet season, average chemical concentration of potassium, nitrates, sulphates and chlorides are high due to excessive water erosion with chemical fertilizers from the agricultural farms into the canal due to gravity and rate of infiltration but it decreases in dry season due to exposure to solar radiation, oxidation and absorption by algal flora, peripheral swamp vegetation and presence of microphytes.

\section{Conclusion}

Based on the chemical analysis, Yatta Canal water is not soft due to chemical contamination especially nitrate which is more than recommended level. $\mathrm{pH}$ of canal water between 6-8 may be safe for irrigation but if it fluctuates too much, then it will be the cause of acidic / alkaline soils. In the dry season, water quality for irrigation is within local and international recommended levels $[44,45]$. It is recommended that farmers should not use large quantities of agrochemicals.

\section{References}

1. Ndeda LA, Manohar S (2014) Bio concentration factor and translocation ability of heavy metals within different habitats of hydrophytes in Nairobi Dam, Kenya. J Environ Sci Toxicol Food Technol 8: 42-45.

2. Ali M, Salam A, Ahmed N, Khan BYA, Khokhar MY (2004) Monthly variation in physico-chemical characteristics and metal contents of Indus River at Ghazi Ghat, Muzaffargarh, Pakistan. Pakistan J Zool 36: 295-300.

3. Shahinasi E, Kashuta V (2008) Irrigation water quality and its effects upon soil. Tirana Agricultural University, Tirana, Albania Balwois.

4. Schilling KE, Wolter CF (2001) Contribution of base flow to nonpoint source pollution loads in an agricultural watershed. Ground Water 39: 49-58.

5. Chopra AK, Pathak C, Prasad G (2009) Scenario of heavy metal contamination in agricultural soil and its management. J Appl Nat Sci 1: 99-108.

6. Ndeda LA, Manohar S (2014) Determination of Heavy Metals in Nairobi Dam Water, (Kenya). IOSR J Environ Sci Toxicol Food Technol 8: 68-73.

7. Mang'oka JM (2016) Assessment of Yatta Canal Water quality for irrigation, Machakos County, Kenya. Unpublished MSc Thesis, Kenyatta University Kenya.

8. Ministry of Agriculture, Animal Husbandry and Water Resources (1962) African Land Development in Kenya. The Government printer, Nairobi, Kenya. 19461962. pp: 32-37. 
Citation: Manohar S, Mang'oka JM, Ndunda E, Gathuru G (2017) Assessment of Yatta Canal Water Quality for Irrigation, Machakos County, Kenya. J Environ Anal Toxicol 7: 423. doi: 10.4172/2161-0525.1000423

Page 6 of 6

9. Ministry of Water Development (1984) Yatta Canal Rehabilitation Proposals. Government Printers, Nairobi, Kenya.

10. Ministry of Agriculture and Livestock Development (MOALD) (2009) Annual Report for Agricultural activities, Thika and Machakos District. Government printers, Nairobi, Kenya.

11. Lezberg SL (1988) Political ecology and resource management: An examination of response to soil erosion in Machakos District, Kenya. MA Thesis, Clark University, Worcester, MA, USA.

12. Barber RG, Thomas DB, Moore TR (1981) Studies on soil erosion and runoff and proposed design procedures for terraces in the cultivated, semi-arid areas of Machakos District, Kenya. In: Proceedings of Conservation 80, the International Conference on Soil Conservation.

13. Scott RM, Gethin-Jones GH (1963) The Soils of the Nairobi-Thika-YattaMachakos Area. Government of Kenya, Department of Agriculture.

14. Republic of Kenya (2009) Population and Housing Census, Kenya Nationa Bureau of Statistics, Government printers, Nairobi, Kenya.

15. Machakos County Government (2015) Machakos County Integrated Development Plan 2015. Government Printers, Nairobi, Kenya.

16. APHA (2005) Standard method for examination of water and wastewater. 21st edn. APHA, AWWA, WPCF. Washington, USA

17. APHA (1998) Standard methods for the examination of water and waste water. 20th edn. Washington DC, USA

18. Zar JH (2001) Biostatistical Analysis. Printice-Hall, Englewood Cliffs, NJ, USA.

19. Solomon DJ, Sambrook HT (2004) Effects of hot dry summers on the loss of Atlantic salmon, Salmo salar, from estuaries in South West England. Fisheries Management and Ecology 11: 353-363.

20. Webb BW, Crisp DT (2006) Afforestation and stream temperature in a temperate maritime environment. Hydrological Processes 20: 51-66.

21. Subehi L, Fakhrudin M (2011) Preliminary study of the changes in water temperature at pond Cibuntu. J Ecol Nat Environ 3: 72-77.

22. Adeniyi HA, Mbagwu IG (1990) Study of some physico-chemical factors and heavy metals in Jakarta reservoir. Kano State, Nigeria National Institute of Fresh Water Fisher Research (NFFR). Annual report, pp: 136-140.

23. Mustapha A, Aris AZ, Ramli MF, Juahir H (2012) Spatial-temporal variation of surface water quality in the downstream region of the Jakara River, northwestern Nigeria: A statistical approach. J Environ Sci Health A 47: 1551-1560.

24. Viers J, Dupré B, Gaillardet J (2009) Chemical composition of suspended sediments in World Rivers: new insights from a new database. Science of the total Environment 407: 853-868.

25. Pringle CM, Benstead JP (2001) The effects of logging on tropical river ecosystems. In: The Cutting Edge: Conserving Wildlife in Logged Tropical Forests. Fimbel RA, Grajal A, Robinson JG (eds.). Columbia University Press, New York, USA.

26. Muhammad SA (2004) An ecological study on the Aquatic life of Sarchnar spring, Chaq-chaq and Kiliassan streams, Sulaimani, Kurdistan region of Iraq. Unpublished MSc Thesis, College of Science, University of Sulaimani, p: 142.

27. Acosta JA, Faz A, Jansen B, Kalbitz K, Martínez-Martínez S (2011) Assessment of salinity status in intensively cultivated soils under semiarid climate, Murcia, SE Spain. J Arid Environ 75: 1056-1066.
28. Sainato CM, Losinno BN, Malleville HJ (2012) Assessment of contamination by intensive cattle activity through electrical resistivity tomography. J Appl Geophys 76: 82-91.

29. Lee N, Yee LT, Grinang J (2012) Physico-chemical characteristics in the filling phase of Bakun hydroelectric reservoir, Sarawak, Malaysia. Int J Appl Sci Technol 2: 92-101.

30. Galczynska M, Gamrat R, Burczyk P, Horak A, Kot M (2013) The influence of human impact and water surface stability on the concentration of selected mineral macro elements in mid-field ponds. Water-Environment-Rural Areas 3: 41-54.

31. Kolanek A, Kowalski A (2002) On the contribution of biochemical processes and humic substances to calcium and magnesium concentrations in water courses. Ochr Srod 1: 9-12.

32. Garg RK, Rao RJ, Uchchariya D, Shukla G, Saksena DN (2010) Seasona variations in water quality and major threats to Ramsagar reservoir, India. Afr J Environ Sci Technol 4: 061-076.

33. Gholami S, Srikantaswamy S (2009) Analysis of agricultural impact on the Cauvery river water around KRS dam. World Appl Sci J 6: 1157-1169.

34. Sarmiento AM, Nieto JM, Olías M, Cánovas CR (2009) Hydrochemical characteristics and seasonal influence on the pollution by acid mine drainage in the Odiel river Basin (SW Spain). Appl Geochem 24: 697-714.

35. Li S, Zhang Q (2010) Risk assessment and seasonal variations of dissolved trace elements and heavy metals in the Upper Han River, China. J Hazard Mater 181: 1051-1058

36. Brainwood MA, Burgin S, Maheshwari B (2004) Temporal variations in water quality of farm dams: impacts of land use and water sources. Agric Water Manag 70: 151-175.

37. Blanchard PE, Lerch RN (2000) Watershed vulnerability to losses of agricultura chemicals: Interactions of chemistry, hydrology, and land-use. Environ Sci Technol 34: 3315-3322.

38. Khaleel R, Reddy KR, Overcash MR (1980) Transport of potential pollutants in runoff water from land areas receiving animal wastes: a review. Water Res 14: $421-436$

39. Manahan SE (1993) Fundamentals of Environmental Chemistry. Lewis Publishers, London, p: 504.

40. Letterman RD (1999) Water quality and treatment: a handbook of community water supplies. McGraw-Hill Professional.

41. Tiwari TN, Manzoor A (1988) River pollution in Kathmandu valley (Nepal) suitability of river water for irrigation. Indian J Environ Prot 8: 269-274

42. Haslam SM (1990) River pollution: an ecological perspective. Belhaven Press.

43. Mustapha MK (2008) Assessment of the water quality of Oyun Reservoir, Offa, Nigeria, using selected physico-chemical parameters. Turk J Fish Aquat Sci 8: 309-319.

44. National Environment Management Authority (2006) Environmenta Management and Co-ordination (Water Quality) Regulations, Government Printers, Nairobi, Kenya.

45. FAO (1985) Irrigation Water Management: Training Manual No. 1. Introduction to Irrigation. Rome, Italy. 